\title{
THE MEANING IN KAWNIYYAT VERSES BASED ON SCIENCE-ORIENTED EXEGESIS: AN EVALUATION OF THE ENGLISH TRANSLATION")
}

\author{
Ahmad Bazli Bin Ahmad Hilmi ${ }^{1}$

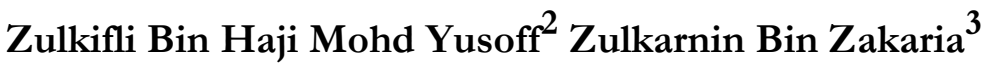

\begin{abstract}
One of the process requirements in the translation of the meaning of Quran is that it must be done by a committee consisting of experts in the field of knowledge related to the Quran such as Arabic language, the target language, the interpretation of Quran and other disciplines such as history, geography, chemistry, biology, medicine and others. It is obvious that Quran is not merely discussing the question of law, but also contains elements of various fields. Kammiyyat verses (verses related to creation) are the Quranic verses which have been typically discussed on the issue of the translation of the meaning of Quran. This is because kamminyat verses indirectly contain elements of science that require the expertise of those involved in the field to provide the exact meaning so that the translations are done in line with the facts of modern science. The objective of this study was to evaluate the meaning of the translation of kammiyyat verses in The Meaning of the Holy Quran by Abdullah Yusuf Ali based on the facts of contemporary science to find out the compatibility between them. In this article, the analysis of the translation of meaning of the verses of Holy Qur'an utilised science-oriented exegesis (tafsir ilmi) to determine whether the translation of meaning matches the modern science facts. The suitable meaning of the verse translation will be proposed then. The result showed some additional values in the translation of meaning of the word 'alaqab in the verse 14 of Sura Al-Mu'minun which is translated into "blood layer/clot", while the more accurate meaning should be "blood layer that characterizes a leech" and the word al-nabl in the verse 68 of Sura Al-Nahl which is translated into "Bee", while the more accurate meaning should be "female bees".
\end{abstract}

Keywords: translation of the meaning, kawniyyat verses, science-oriented exegesis and modern science.

() This article was submitted on: 03/03/2016 and accepted for publication on: 09/05/2016.

1 Ahmad Bazli, Kolej PERMATA Insan, Universiti Sains Islam Malaysia, email: ahmadbazli@usim.edu.my

${ }^{2}$ Centre of Quranic Research, University of Malaya, email: zulkifliy@um.edu.my

${ }^{3}$ Kolej PERMATA Insan, Universiti Sains Islam Malaysia, zulkarnin@usim.edu.my 


\section{INTRODUCTION}

While the Quran translation activity in Malaysia has been developed for a long time, there was no clear guide or standard approach that has been used in the process. This has caused a few problems in the existing translation that created confusions in the meaning given. This problem has encouraged academics to come up with a few guidelines and methods in the translation process to ensure the work produced will not affect the quality and standard of the premier source of teaching in Islam.

Among the method suggested is to ensure that the translation of Quran be done by a special committee consisted of experts from various fields of study such as Arabic, translation and interpretation. In addition, the participation of experts from literature, history, geography, chemical, biology, medical, engineering, law and other fields is a must since Quran covers not only issues on religious right or wrong as it contains elements from various subjects. ${ }^{1}$ The translation without input from experts might produce inaccurate translation as the saying goes "two heads are better than one." There is also a suggestion to develop a Quranic Translation Review Committee that is made of experts from relevant body to help maintaining the trustworthiness of the translated Quran. ${ }^{2}$

Based on this assumption and suggestion, the researcher decided to reevaluate the Quranic verses that have been usually misinterpreted especially those related to creation or popularly known as kawniyyat verses. These verses indirectly consist scientific elements that require those with relevant background to understand the exact meaning so that the translation made concur with the contemporary science facts. The research focused on the study of Quranic verses related to the creation of the human based on science-oriented exegesis (tafsir ' ilmi). The translation was made in accordance to the latest science

${ }^{1}$ Nur Lubis. (2004). "Penterjemahan Makna Al-Qur'an: Kajian ke arah Melahirkan Kaedah Penterjemahan Makna Al-Qur'an"(Phd thesis, University of Malaya, Kuala Lumpur), pp. 546-647.

${ }^{2}$ Mohd Shukri Hanapi. (2003). Terjemahan Al-Qur'an Dalam Pelbagai Perspektif. Kuala Lumpur: Utusan Publications \& Distributors Sdn. Bhd., pp. 226. 
discovery to ensure the translations of meaning are linked to modern science facts.

\section{DEFINITION OF KAWNIYYAT VERSES (Al-AYAT $A L$ - KAWNIYYAT)}

Kawniyyat verses (Al-Ayat Al-Kawniyyat) is the combination of two words Al-Ayat and Al-Kawniyyat. The meaning of each word will be defined before the discussion on the meaning of kawniyyat verses.

Al-Ayatis an Arabic word in the singular form, while the plural form for it could either be $A l-A y a t$ or $A l-A y$. From language perspective, $A l$-Ayat has a few meanings, among them is the sign or mark. ${ }^{1}$ According to Al-Shaybani, Al-Ayat also means a group or class. Other meaning for Al-Ayat is a person himself as in the phrase "ayat Al-Rajul" that means himself. For Al-Ayat from Kitabullah, they are group of letters or words which are based on oral expressions. ${ }^{2}$ This is the meaning of Al-Ayat used in this paper. The use of Al-Ayat would refer to the verses of the Holy Quran.

The word Al-Kawn is derived from the word kana that means the universe (covers all living things that have place and time), the plural form of kawn is akwan. ${ }^{3}$ In other word, the meaning of Al-Kawn refers to all type of creations such as the sky, earth, mountains, rivers, animals, plants, human and other creatures. Kawniyyat is the modifier to AlKawn $^{4}$ that functions as an adjective to Al-Ayat.

The combination of words Al-Ayat and Al-Kawniyyat can be defined as all the verses of the Quran that illustrate the creation or universe directly or indirectly. This is the meaning used in this paper.

${ }^{1}$ Al-Fayruzabadi, Muhammad IbnYa'qub. (2005). Al-Qamus Al-Muhit. Beirut: Muassasat AlRisalah, $8^{\text {th }}$ ed., pp. 1261.

${ }^{2}$ Zulkifli Mohd Yusof. (2009). Kamus Al-Quran: Rujukan Lengkap Kosa Kata Dalam Al-Quran. Selangor: PTS Islamika Sdn. Bhd., pp. 121.

3'Ammar, Ahmad Mukhtar. (2008). Mu'jam Al-Lughah Al- 'Arabiyyat Al-Mu 'asarat. Kaherah: 'Alam Al-Kutub, pp. 1974.

${ }^{4}$ Ibid. 


\subsection{THE NUMBER OF KAWNIYYATVERSES}

The actual number of kawniyyat verses cannot be exactly determined. Even scholars have their own differences on this matter. Al-Shaykh Tantawi Jawhari who is regarded as the leading scholar on this matter stated in his interpretation that there are more than 750 kawniyyat verses that mentioned all the wonders of the world. ${ }^{1}$ Some scholars estimated that there are more than 900 kawniyyat verses in the Holy Quran. ${ }^{2}$

While Dr. Zaghlul Al-Najjar claimed that the number of verse that signal the type of kawniyyat verses in Quran according to researchers are almost 1000 verses which are mentioned clearly and many other verses which are almost similar to the signal. ${ }^{3}$

It can be observed that the opinion on the number of kawniyyat verses had increased with time and scientific development. The factor in number differences could be due to the interpretation of meaning of Quranic verses in tandem with the development of knowledge and technology that are not known before, as Allah SWT mentions:

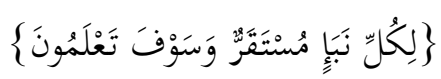

The translation of the meaning:

"For every message is a limit of time, and soon shall ye know it." (al-An'am:

\subsection{GENERAL PRINCIPLE IN THE DISCUSSION OF $A L$ - $K A W N$ IN QURAN}

Based on the observation towards kawniyyat verses in Al-Quran, there are several general principles that are used in the discussion of such verses. It

${ }^{1}$ Tantawi Jawhari. (1922). Al-Jawahir fi Tafsir Al-Qur'an Al-Karim. T.tp: Maktabah wa Matba'ah Mustafa Al-Babi Al-Halabi wa Awladihi bi Misr, v. 1, pp. 2

${ }^{2}$ Mustafa Muslim. (1996). Mabahith fi I'jaz Al-Qur'an. Riyad: Dar Al-Muslim li Al-Nashr wa AlTawzi', $2^{\text {nd }}$ ed., pp. 168.

${ }^{3}$ Al-Najjar, Zaghlul. (2007). Tafsir Al-Ayat Al-Kawniyyat fi Al-Qur'an Al-Karim. Kaherah: Maktabat Al-Shuruq Al-Dawliyyat, v. 1, pp. 26

${ }^{4}$ All translations of Al-Quran verses in this paper is based on the work by Abdullah Yusuf Ali. (1999). The Meaning of The Holy Qur'an, Kuala Lumpur, Islamic Book Trust. 
is agreed that such principles would help a clear picture in understanding the verses. Those principles are ${ }^{1}$ :

a) Al-Quran does not stress on the information on creation as a central topic. The fundamental reason for the revelation of Al-Quran is to serve as a guide to human beings, as Allah SWT said:

$$
\{\text { \{ المُ ذَلِكَ الْكِتَابُ لَا رَيْبَ فِيهِ هُدَى لِلْمُتَّقِينَ }
$$

The translation of the meaning:

"This is the Book; in it is guidance sure, without doubt, to those who fear Allah." (al-Baqarah : 2)

In reality, Allah SWT has never included theories of science in the holy Quran. ${ }^{2}$ Without proper guidance, the knowledge would only lead to more destructions. For instance, the advantage of human ability to utilise nuclear to generate energy could be abused in the form of nuclear weapons and it could pose a bigger threat. Al-Quran however has always taught that the basis of knowledge should be understood from the correct perspective and there should be an effort to avoid the growth of malicious ideas.

b) Knowledge on nature is based on the continuous development of science on daily basis, resulting in Al-Quran allowing the debate on scientific theories open for human to investigate. Similarly, there are other areas of life such as lifestyle, career, economy, and carpentry that allow human to decide. Al-Quran supports the knowledge on nature and encourages human to observe Allah's creations and discover the secrets they hold.

c) Al-Quran has established that all creations of Allah serve to assist human in various aspects of life and help human to optimize their life. It simply proves that there is no conflict between religion and science, and there are many Islamic scholars then and now who were

1 'Atar, Nur Al-Din. (1993). 'Ulum Al-Qur'an Al-Karim. Dimashq: Matba'at Al-Sabah, pp. 236237.

${ }^{2}$ It refers to detailed scientific theories, while Al-Qur' an describes fundamental theories of scientific knowledge. The Prophet himself has even said: "You understand your world better," when he was asked about plant propagation. 
deeply knowledgeable in religion while at the same time become experts in science just like Ibnu Sina. Obviously there is no hate between Islam and science because Allah's creations, based on Quranic perspective are facilities to human. Al-Quran mentioned clearly on the relationship between the creations and human with the word (sakbkhara) that means "continuous service", as Allah SWT said:

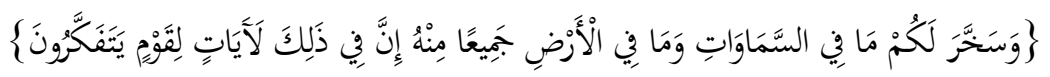

The translation of the meaning: "And He has subjected to you, as from Him, all that is in the heavens and on earth: Behold, in that are Signs indeed for those who reflect." (al-Jathiyah: 13)

d) Al-Quran discusses the fact of creation and has never explained the theories of science. It however elucidates and attracts the attention on the wonder of Allah's creations and reminds the existence of a Creator and gifts to human from Allah. Both are inter-related with the objectives of Al-Quran which is to guide human being, as it contains the blessings for human being, and with the realization comes gratefulness, obedience and taqarrub towards Allah SWT.

\section{THE TRANSLATION OF THE MEANING OF $A Y A T$ KAWNIYYAT AND TAFSIR 'ILMI}

The translation of the meaning of Al-Quran cannot be separated from the exegesis of Quran (tafseer). The actual meaning of Quranic verses cannot be achieved without the exegesis (tafseer). That is the reason why the meaning translation allowed by shara' is the translation using tafsiriyyat approach as there was no difference in the rules of tafseer because tafsiriyyat translation covers all criteria of the exegesis (tafseer). It is even considered as fard kifayah (obligation to some Muslims) for many.

Since kawniyyat verses have a direct connection to natural knowledge, the best way to know the meaning of kawniyyat verses is using the tafsir ilmi (science-oriented exegesis). According to Salah 'Abd Al-Fattah Al-Khalidi,tafsir ilmi is a scientific approach to AlQuran exegesis that meet the modern science methods and descriptions of the meaning of Al-Quran in tandem with the current science 
discovery and analysis. ${ }^{1}$ However, tafsir 'ilmi has its own standard that needs to be met as follows ${ }^{2}$ :

First: Al-Quran is a book of guidance. Al-Quran Al-Karim serves as a guide to remind human of their responsibility as the khalifah (leader) of Allah on earth.

Second: Not too extreme and inconsiderate. The research on kawniyyat verses cannot go beyond acceptable level of interpretation and cannot avoid the positive aspects found in nature as provided by Allah for human consumption.

Third: The approach of Al-Quran translation is flexible as it can accept suitable meanings.

Fourth: Scientific facts are the base of proof. Scientific observation and theories that cannot fulfil scientific facts should be avoided.

Fifth: The verse cannot be interpreted solely on one assumption. Sometimes scientific facts can be interpreted in many ways and not limited to only one meaning.

Sixth: It is impossible that there will be any contradiction between AlQuran and science facts. It is known that both come from the same source.

Seventh: One should adhere to the Al-Quran method in knowledge development. It is important to understand that every incidence that happens is somehow linked to the time period. Thus it is mentioned that the best interpreter of Al-Quran is the time period.

\section{RE-EVALUATION OF KAWNIYYAT VERSES TRANSLATION BASED ON SCIENCE ORIENTED EXEGESIS}

\footnotetext{
${ }^{1}$ Salah 'Abd Al-Fattah Al-Khalidi. (2008). Ta'rif Al-Darisin bi Manahij Al-Mufassirin. Dimashq: Dar Al-Qalam, $3^{\text {rd }}$ ed., pp. 566.

${ }^{2}$ Abdul Rashid Ahmad. (2009). Aspek-Aspek Kemukjizatan Al-Qur'an, Jurnal Al-Bayan, v.7, pp. 51-52.
} 
In order to illustrate the re-evaluation of the meaning of Al-Quran using science oriented exegesis, the writers present two samples in the reevaluation of the translation in the Kawniyyat verses in the Quran:

\section{SAMPLE 1: 'ALAQAH}

Allah SWT stated in verse 14, Sura Al-Mu'minun:

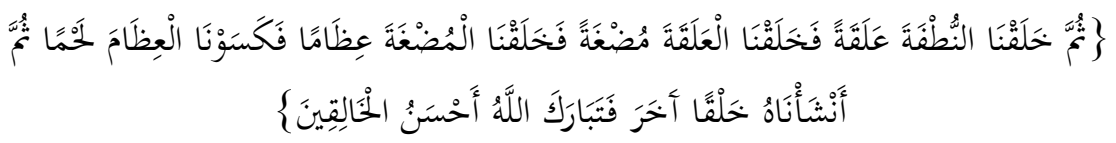

The translation of the Meaning:

"Then We made the sperm into a clot of congealed blood; then of that clot We made a [foetus] lump; then we made out of that lump bones and clothed the bones with flesh; then we developed out of it another creature. So blessed be Allah, the best to create!" (al-Mu'minun: 14)

Verse 14 Al-Mu'minun above generally describes the development of embryo that goes through a few phases before birth and they are nutfah, 'alaqah, mudghah, 'izam and khalq akhar. Al-Quran mentioned this fact almost 1400 years ago, while scientists only managed to recently discover the embryo development after the invention of microscope, a device never existed 1400 years ago. The first person in the world who used microscope to study the human sperm (spermatozoa) was Ham and Leeuwenhoek in the year 1677, more than 1000 years after the birth of this verse. However back then, Hamm and Leuwenhoek were still in the dark in explaining the embryo development. ${ }^{1}$

The facts mentioned in Al-Quran are therefore referred to tafsir ilmi regarding the verse to determine whether the translation given matched the modern science facts in embryology and the technology development today. The word that became the topic of discussion in the verse was 'alaqah (علقة) It could be found that the given meaning of 'alaqah was a clot of congealed blood. The debate on the meaning was further explained here: 'Alaqah is the development after nutfah. This

${ }^{1}$ Moore, Keith L. et al. (2008). The Developing Human: Clinically Oriented Embryology. Philadelphia, PA: Elsevier Saunders, $8^{\text {th }}$ ed., pp.10, also see Bullough, Vern L. (2001). Encyclopedia of Birth Control (California: ABC-CLIO, pp.208. 
stage begins from day 15 and ends on day 23 or $24 .{ }^{1}$ The word 'alaqah is found at five places in Al-Quran, three of them is mentioned in nakirah form(general noun) which are Surah Al-Hajj: Verse 5, Surah Ghafir: Verse 67 and Surah Al-Qiyamah: Verse 38, while inverse 14 Surah Al-Mu'minun, it is mentioned both as nakirah and ma'rifah (proper noun). In another place, 'alaqah is mentioned in plural form that is 'alaq in Surah Al-'Alaq: Verse 2.

When it is referred to various tafseer, mufasir gave multiple translations to the word 'alaqab that include the following meanings ${ }^{2}$ :

1. Blood in general: 'Ikrimah view

2. A slice of dried blood: Al-Shawkani and Al-Alusi opinion

3. A small lump of blood: Al-Jaza'iri

4. A wet slice of blood: Al-Qurtubi

5. Reddish-colour blood: Al-Sa'di

6. Dried blood in bright red: Al-Biqa ${ }^{9} \mathrm{i}$

7. 'Alaqab in red in the shape of long leech: Ibn Kathir

8. A small worm which is brighter than red colour of blood: Ibn 'Uthaymin

9. Dried blood spots that stick to the uterus: Sayyid Qutb

It can be concluded from the various meanings of 'alaqah based on mufassir is a slice of blood in a lumpy condition, dried, damp, red in colour and is leech-shape.

There were even claims that it was called 'alaqah because of its characteristic that sticks to the blood vessels on the uterus and obtaining the energy from the mother. ${ }^{3} \mathrm{Al}-\mathrm{Sh}$ ' rawi cited 'alaqah as a fertilized egg and scientist named it zygote that acquired its food from the uterus. That is the reason why women who are not pregnant will

${ }^{1}$ Esmailzadeh Mahdi et. al. (2012). “Developmental Biology in Holy Quran”, Journal of Physiology and Pathophysiology Vol. 3(1), pp.3.

${ }^{2}$ Al-Mushaf Al-Jamic website, updated on 19 September 2013, https://mosshaf.com/main

${ }^{3}$ Ibn 'Ashur, Muhammad Al-Tahir. (1884) Tafsir Al-Tahrir wa Al-Tanwir (Tunisia: Dar AlTunisiyyah, v.18, pp. 23-24. 
experience period, while pregnant ones would have the blood converted as the food for the embryo. ${ }^{1}$

From linguistic point of view, the word 'alaqah is the derived word from the word 'alaqa that means sticking to and relying on while the compound word for 'alaqah is 'alaq. The word 'alaqah refers to a dried slice of blood which is a stage in embryo development. Other meaning of 'alaqah is a black blood-sucking worm that lives in contained water, and it relies on its jaw when it is sucking blood from various animals. ${ }^{2}$ The Arab community calls a leech 'alaqah because of its characteristic that sticks to other creature. ${ }^{3}$

The researcher then referred to the modern science facts to cover a bigger picture of the meaning. According to the knowledge on embryology, human development begins with the fertilisation of the sperm and ovum to create a unique cell called zygote. The zygote contains all genetics information (DNA) needed by a baby. The zygote moves down through the fallopian tube towards the uterus.

While moving, the zygote cells continuously split itself to shape a 'little ball of cells' known as blastocyst. Blastocyst then sticks to the uterus on the sixth day and plant itself continuously around the womb with the cells until it develops the placenta. This process would take more than a week until cell differentiation occurs, developing the embryo and placenta from the blastocyst. The embryo then sticks to the primitive placenta and hangs by the cell junctions which would finally become the umbilical cord (refer to Diagram 1). ${ }^{4}$ This fits the

${ }^{1}$ Al-Sha'rawi, Muhammad Mutawalli. (n.d). Tafsir Al-Sha'rawi (Kaherah: Dar Akhbar Al-Yawm, t.tp), v.16, pp. 9979-9980.

2‘Umar, Ahmad Mukhtar. (2008). Mu'jam Al-Lughah Al-Arabiyyah Al-Mu'asirah (Kaherah: 'Alam Al-Kutub, v.3, pp. 1537-1539.

3 The Arab community like to name an animal based on its characteristic, for instance an ant is called namlah because it walks a lot.

${ }^{4}$ Elias Kareem, (2013). "Embryology in the Qur'an: The 'Alaqah Stage”, The Quran Project website, retrieved September 21, 2013 from http://www.quranproject.org/Embryologyin-the-Quran-The-Alaqah-Stage-491-d 
meaning of 'alaqah in the compound word 'alaqa that is something that sticks and hangs.

On another note, Emeritus Professor Keith Moore ${ }^{1}$ claimed that 'alaqah referred to a leech that resembled the embryo at the age of 7 to 24 days when it glued itself to the uterus endometrium just like a leech would do to the skin. Just like a leech that sucks the blood from the victim, human embryo receives it supplies from the decidua. It is amazing to state that the embryo at the age of 23 to 24 days resembles the shape of a leech (refer Diagram 2), as there was no microscope or lens available during the 7 th century and doctors never knew that human embryo actually resembled a leech. Embryo can only be seen by the naked eyes as early as the fourth week because the size is smaller than a wheat. ${ }^{2}$

When we observed the primitive cardiovascular system in an embryo aged 21 days, it was found that the external appearance of an embryo and its container was similar to a blood clot. This was due to the existence of chorionic pouch, primitive heart and cardiovascular system (refer to Diagram 3). Blood would not flow until the end of the third week even in the form of liquid. On the 21 st day, the heart of the embryo connects the blood vessels in the embryo, the connecting passage, chorion and centre of vesicle. The blood later flowed and the heart started to beat. ${ }^{3}$ The embryo took the form of a blood clot even though the blood is in liquid form (refer to diagram 4) and this illustrated the real meaning of 'alaqah which is a lump of dried blood clot.

Based on the description given, the word 'alaqah used in AlQuran was a concept generally referred to the second stage of embryotic development that explained the external look of embryo and its internal characteristics; a common shape of an embryo as a leech was described; internal processes such as blood formation and the close

${ }^{1}$ He was an anatomy and embryology expert from the University of Toronto, Canada.

${ }^{2}$ Moore, Keith L. (1986). "A Scientist's Interpretation of References to Embryology in The Qur'an", Journal of the Islamic Medical Association, v.18, pp.15-16.

${ }^{3}$ Elias Kareem, "Embryology in the Qur'an". 
passage were also mentioned; and the sticking of embryo to the placenta was also highlighted. The use of the word 'alaqah satisfied three meanings from linguistic point of view:

i- Something that sticks or parasite-like.

ii- A lump of blood.

iii- Leech-like.

The researcher agreed that the first meaning was covered in the third meaning because the Arab community called a leech 'alaqab because of its feature that sticks or relies on another creature. There are shocking similarities of both as listed here ${ }^{1}$ :

1. The outer look of a leech resembles an embryo at the age of 22-25 days.

2. The internal structure of a leech look like an embryo at the age of 22-26 days.

3. Embryo sticks to the outer layer of the uterus just like a leech to our skin.

4. Embryo gets the nutrient from the mother's blood, similar to a leech sucking blood from people.

5. Embryo has segmented body such as a worm or a leech.

It clearly shows that the meaning of "alaqah as a "leech" is more dominant because embryo shares similar features with leech. Hence, the limited meaning of "alaqah as a "lump of meat" or "sticky object" did not represent the "leech" aspect shown in ijaz "ilmi (science miracles) of Al-Quran.

Thus the suitable translation of the word 'alaqah would be "a slice/lump of blood that assembles a leech characteristics" and it shares similar features between an embryo and a leech.

\section{SAMPLE 2: AL-NAHL}

Allah SWT stated in verse 68, surah al-Nahl: 


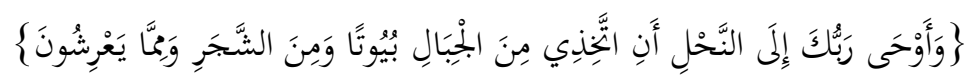

Meaning: And thy Lord tanght the Bee to build its cells in hills, on trees, and in [men's] habitations

The focus in this verse is the word " النحل" which is translated as a "bee". The word "bee" is too general because it does not indicate whether it is male or female. This could lead to a confusion on the gender of the bee as they perform different functions in their daily life activities.

According to Lisan al-'Arab, النحل gives the meaning of honey fly, the singular unit is . النحل is mudhakear because its phrase is mudhakkar, while it is used as mu'annath because the phrase of النحلة is the plural noun of Allah SWT has stated it as mu'annath according to the verse “" "أن اتخذي من الجبال بيوتا"This matter attracts the attention of tafsir ulama to deeper study by observing modern science fact. It is apparent that the verse has ifjaz that is unknown previously.

Bee is the common name of insect family in the class of hymennoptera. Some live collectively and some individually. It is divided into some identifiable classification, including:

i. Andrenidae : Wild bee that live underground.

ii. Megachiledae : Leaf cutter bee

iii. Xylocopidae : Carpenter bee

iv. Bombidae : Bumble bee

v. Apidae : Honey bee

In the verse, Allah SWT stated that He has given inspiration to the bees by mentioning the bee in general. Yet, it is understandable that the referred bee is the honey bee. Thus, the next discussion is specific

${ }^{1}$ Ibn Manzur, Muhammad Ibn Mukarram. (n.d). Lisan al-'Arab. Beirut: Dar Sadir 2:118.

${ }^{2}$ Al-Azhari, Muhammad Bin Ahmad. (2001). Tahzib al-Lughah. Beirut: Dar Ihya' al-Turath al'Arabi, 5:42. 
to the honey bee. It is one of the social insects that lives in colony. Each colony usually consists of ${ }^{1}$ :

\section{Queen Bee:}

The fertile female bee. The task of the queen is to move above the bee nest, check the nest and lay eggs on the empty compartment and get ready to receive them, control the whole activities of the bee colony. The Queen produces two types of eggs; the fertilized eggs that bear female bees and queen, while the ones that have not been fertilized will become male bees.

\section{Male Bees:}

The fertile male bee, which is produced by most of honey bee colonies started from the month of Mei until July. The sole function of this bee is to mate with the queen bee.

\section{Worker Bees:}

They are the infertile female bees. Worker bees carried out vital tasks for the development and continuance of colony such as feeding and taking care of the young from the queen eggs, build new nest, repair the existing nest, defend the colony and search for food, water and propolis (a resinous mixture that honey bees collect from tree buds, sap flows, or other botanical sources that used as a sealant for unwanted open spaces in the bive)

In a glance, this bee colony is almost the same with the ant colony discussed earlier.

A fascinating fact here is that half of the alimentary canal in the frontal abdomen of a worker bee is enlarged in order to form a honey stomach whereby honey is collected and brought back to the nest. ${ }^{2}$ This is explained by Allah SWT in His next verse: يخرج من بطوها شراب (came out from its stomach a liquid). The pronoun of mu'annath (feminine) strengthens the statement that the indicated bee in the former verse is a female bee.

\footnotetext{
${ }^{1}$ Free, John B. (1982). Bees and Mankind (London: George Allen \& Unwin Publishers, 42-45.

${ }^{2}$ Ibid, 49-50.
} 
Based on the facts related to honey bees, the understood meaning in the mentioned verse is directly referring to the worker female honey bee. This is because of their specific job scope which is to build nest and fly hundreds of kilometres to collect floral honey and pollen seeds from various types of flowery plant. This female bee worker is the one that has been given the capacity from Allah SWT to produce the liquid known as honey. ${ }^{1}$

It is clear that the word النحل in the verse is a female bee and it is insufficient to be translated as just "bee" as it was too general. The authors propose that the translation of the meaning is "female bees" and a brief description on these female bees being from the honey bee type.

\section{CONCLUSION}

Based on the discussion above, the existing English translation of AlQuran can be updated and matched with current scientific facts such as the translation of the words 'alaqah and al-nabl. The suggested meaning for "alaqah is "a piece/a small lump of blood that assembles the characteristics of a leech" and for the word al-nabl is "female bees". Specific meaning has to be used to ensure reciters who read the Quranic translation of the verses understand it clearly and correctly. The meaning given in the translation should reflect Al-Quran as the book of knowledge that alleviates its quality as the main reference in the life of all Muslims.

The continuous effort to improve the translation of Al-Quran will bring great advantage to Islam and Muslim community as a whole. Since Al-Quran is widely read in English, it is logical to focus on the improvement of its translation in this language. This is a vital effort in ensuring the position of Al-Quran as the greatest mukjizat suitable for any period in time and will never be obsolete. This approach is in line with the uslub of this era of knowledge development and technological advancement where society demands empirical proof in accepting any

${ }^{1}$ Al-Najjar, Zaghlul. (2007). Tafsir al-Ayat al-Kawniyyat fi al-Qur'an al-Karim Kaherah: Maktabat al-Shuruq al-Dawliyyat, 1:496. 
claim made on any matter. This effort is expected to be a trigger of the exposing of the miracle of Quran for non-Muslims. 


\section{REFERENCES}

Abd Razak, M. N. (2004). "Penterjemahan Makna Al-Quran: Kajian ke arah Melahirkan Kaedah Penterjemahan MaknaAl-Quran”. Phd thesis, Universiti of Malaya, Kuala Lumpur.

Abdul Rashid, A. (2009). "Aspek-Aspek Kemukjizatan Al-Quran”. Jurnal AlBayan, v.7, pp. 35-58.

Al-Azhari, M. A. (2001). Tahzib al-Lughah. Beirut: Dar Ihya' al-Turath al'Arabi.

Al-Bugha, M. D. \&Mastu, M. Di. (1998). Al-Wadih fi 'Ulum Al-Quran Dimashq: Dar Al-Kalim Al-Tayyib, $2^{\text {nd }}$ ed.

Al-Dimashqi, I. U. (2000). Tafsir Al-Quran Al-'Azim. Cairo: Muassasah Qurtubah.

Al-Fayruzabadi, M. Y. (2005). Al-Qamus Al-Muhit. Beirut: Muassasah AlRisalah, $8^{\text {th }}$ ed.

Al-Khalidi, S. (2008). Ta'rif Al-Darisin bi Manabij Al-Mufassirin. Dimashq: Dar Al-Qalam, 3rd ed.

Al-Mushaf Al-Jami' website, updated September 19, 2013, https://mosshaf.com/main

Al-Najjar, Z. (2007). Tafsir al-Ayat al-Kawniyyat fi al-Quran al-Karim. Cairo: Maktabat al-Shuruq al-Dawliyyat.

Al-Sha'rawi, M. M. (n.d). Tafsir Al-Sha'rawi. Cairo: Dar Akhbar Al-Yawm.

Al-Shatibi, I. M. (1997). Al-Muwafaqat. Cairo: Dar Ibn 'Affan.

Ammar Fadzil. (2007). Anatomi Al-Quran: Mengenal Ilmu, Sejarab \& Kandungan Al-Quran Selangor: PTS Publication \& Distributors Sdn. Bhd..

Bullough, V L. (2001). Encyclopedia of Birth Control. California: ABC-CLIO.

Esmailzadeh M. et. al. (2012). "Developmental Biology in Holy Quran". Journal of Physiology and Pathophysiology, Vol. 3(1), pp. 1-7.

Free, J.B. (1982). Bees and Mankind. London: George Allen \& Unwin Publishers.

Ibn 'Ashur, M. T. (1884). Tafsir Al-Tahrir wa Al-Tanwir. Tunisia: Dar AlTunisiyyah.

Ibn Manzur, M. M. (n.d), Lisan al-'Arab. Beirut: Dar Sadir.

Jumu'at, M. A. et al. (2002). Al-Mawsu'ah Al-Quraniyyah Al-Mutakhassisah. Cairo: Wizarah Al-Awqaf Misr.

Kareem, E. (2013). "Embryology in the Quran: The "Alaqah Stage", The Quran Project website, retrieved September 21, 2013 from http://www.quranproject.org/Embryology-in-the-Quran-TheAlaqah-Stage-491-d 
Mohd Shukri Hanapi. (2003). Terjemahan Al-Quran Dalam Pelbagai Perspektif. Kuala Lumpur: Utusan Publications \& Distributors Sdn. Bhd.

Moore, K. L. (1986). “A Scientist's Interpretation of References to Embryology in The Quran", Journal of the Islamic Medical Association, v.18, pp.15-16.

Moore, K. L. et al. (2008). The Developing Human: Clinically Oriented Embryology. Philadelphia, PA: Elsevier Saunders, $8^{\text {th }}$ ed.

Umar, A. M. (2008). Mu'jam Al-Lughah Al-'Arabiyyah Al-Mu'asirah. Cairo: 'Alam Al-Kutub.

Yusuf Ali, A. (1999). The Meaning of the Holy Quran. Kuala Lumpur, Islamic Book Trust.

\section{APPENDIX:}

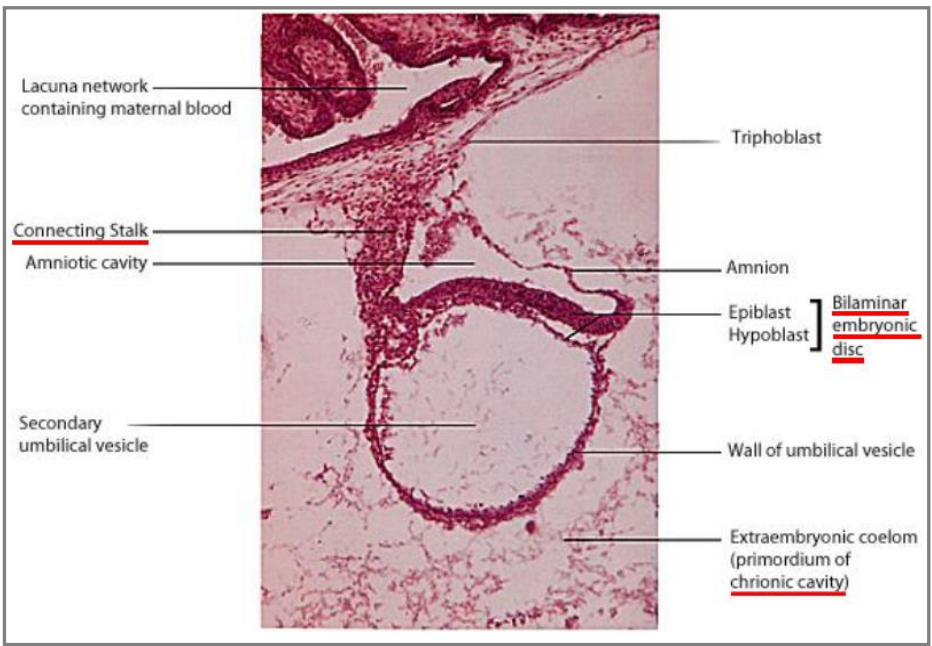

Diagram 1: Source: Embryology in the Quran: The 'Alaqah Stage

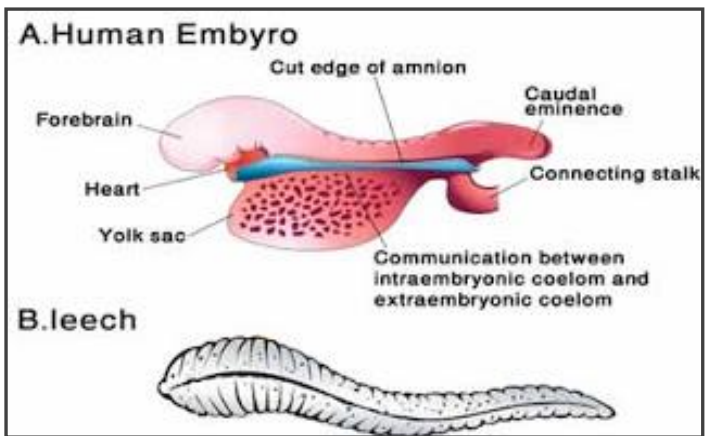

Diagram 2: Source: Embryology in the Quran: The 'Alaqah Stage 

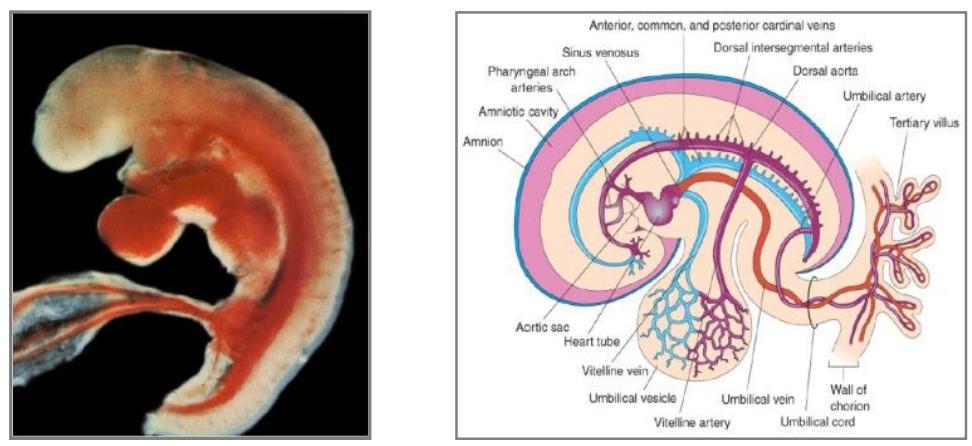

Diagram3 \& 4: Source: Embryology in the Quran: The 'Alaqah Stage 